\title{
Effect of Iron Supplementation in Anti-Tuberculosis Drug Treatment on Interferon- $\gamma$ Level in Tuberculosis Spondylitis Patients
}

\author{
M. F. Nanda Perdana, Hermawan Nagar Rasyid, Ahmad Ramdan, Yoyos Dias Ismiarto \\ Department of Orthopaedics and Traumatology Faculty of Medicine Universitas Padjadjaran \\ Dr. Hasan Sadikin General Hospital Bandung, Indonesia
}

\begin{abstract}
Tuberculosis (TB) is still one of the major health problems in the community. Micronutrients, including iron, are crucial in the body's defense mechanism. Iron modulates the activation of IFN- $\gamma$, which in turn will activate the macrophages. This study explores the effect of iron supplementation given with anti-tuberculosis drug therapy on the IFN- $\gamma$ level in tuberculosis spondylitis patients. This was a single-blind randomized control trial study at Dr. Hasan Sadikin General Hospital Bandung, from December 2018 to March 2019, using the consecutive sampling approach. Thirty-four respondents with category $1 \mathrm{~TB}$ spondylitis and an sTfR level of $>21.7 \mathrm{pg} / \mu \mathrm{L}$ were recruited and randomized into control and experimental groups. The control group $(n=17)$ was treated with 2 RHZE for 2 months while the experimental group ( $n=17)$ received 2 RHZE and iron tablet for 2 months. An increase in the IFN- $\gamma$ level of the experimental group was observed from an average of $21.7 \mathrm{pg} / \mathrm{mL}$ before therapy to an average of $72.39 \mathrm{pg} / \mathrm{mL}$ after therapy. Meanwhile, the IFN- $\gamma$ level in the control group increases from an average of 22.5 $\mathrm{pg} / \mathrm{mL}$ to an average of $35.35 \mathrm{pg} / \mathrm{mL}$. This difference was statistically significant based on the analysis using the independent t-test ( $\mathrm{p}$-value $<0.05$ ). Therefore, the administration of anti-tuberculosis drugs with the addition of iron can increase the body's immune response, which is indicated by the increasing level of IFN- $\gamma$.
\end{abstract}

Key words: Interferon- $\gamma$, iron supplementation, spondylitis TB

\section{Pengaruh Penambahan Zat Besi Pada Pengobatan Obat Anti Tuberkulosis Terhadap Kadar Interferon- $\gamma$ Pada Pasien Spondilitis Tuberkulosis}

\begin{abstract}
Abstrak
Tuberkulosis (TB) masih merupakan salah satu masalah kesehatan yang cukup besar di masyarakat. Gangguan imunitas tubuh penderita berperan dalam proses terjadinya infeksi tuberculosis. Mikronutrient yang penting dalam pertahanan tubuh salah satunya adalah zat besi. Pada penelitian ini akan dipelajari mengenai pengaruh penambahan zat besi pada terapi OAT terhadap kadar IFN- $\gamma$ pada pasien spondilitis tuberkulosis. Penelitian ini merupakan penelitian dengan metode single blind randomized control trial di Rumah Sakit Dr. Hasan Sadikin Bandung pada Desember 2018 hingga Maret 2019 dengan metode pengambilan sampel consecutive sampling. Dilakukan randomisasi pada 34 responden. Responden yaitu: penderita spondilitis TB kategori 1 dengan kadar STfR $>21,7 \mathrm{pg} / \mu \mathrm{L}$. Kelompok kontrol 17 responden diterapi 2 RHZE. Kelompok eksperimen 17 responden diterapi 2 RHZE dengan tablet besi selama 2 bulan. Pada penelitian ini didapatkan peningkatan kadar IFN- $\gamma$ rata-rata kelompok eksperimen (pemberian obat anti tuberkulosis dengan penambahan zat besi) dari 21,7 pg/mL sebelum dilakukan pemberian terapi menjadi rata-rata $72,39 \mathrm{pg} / \mathrm{mL}$ setelah dilakukan pemberian terapi diuji dengan uji t sampel independen (nilai $\mathrm{p}<0,05$ ), secara statistik berbeda signifikan dengan kelompok kontrol (pemberian obat anti tuberkulosis), yaitu dari $22,5 \mathrm{pg} / \mathrm{mL}$ sebelum dilakukan pemberian terapi menjadi rata-rata 35,35 pg/mL setelah dilakukan pemberian terapi. Simpulan, pemberian obat anti tuberkulosis dengan penambahan zat besi dapat meningkatkan respon imun tubuh, yang ditandai dengan meningkatnya kadar IFN- $\gamma$.
\end{abstract}

Kata kunci: Interferon- $\gamma$, spondilitis TB, zat besi

Corresponding Author: M. F. Nanda Perdana, Department of Orthopaedics and Traumatology Faculty of Medicine Universitas Padjadjaran/Dr. Hasan Sadikin General Hospital Bandung, Jalan Pasteur No 38 Bandung, West Java, Indonesia, Email: nandaperdana@ymail.com 


\section{Introduction}

Spondylitis TB affects approximately $1-5 \%$ of the total TB patients. ${ }^{1,2}$ There are about 3 million deaths that occur each year due to this disease, making this disease one of the biggest health problems often found in society, especially in Indonesia. ${ }^{3}$

Recovery from tuberculosis is declared based on various factors, one of which is the Interferon- $\gamma$ (IFN- $\gamma$ ) level. An increase in the IFN- $\gamma$ level reflects an increase in the patient's immune response. Thus, the IFN- $\gamma$ level can be used as a biomarker for tuberculosis recovery based on the measurement of the amount of IFN- $\gamma$ in the blood.

Patients' body immunity plays a role in the process of tuberculosis infection. One of the crucial micronutrients in the body's defense is iron, which is an essential element of living beings and plays a decisive role in the body's defense mechanism against pathogenic microorganisms. Iron deficiency can occur to anyone even if there is no symptom of anemia. ${ }^{4}$ This iron deficiency can be detected through the soluble transferrin receptor (sTfR) level since the increase level of sTfR is the sensitive response to the initial stages of iron deficiency.

No study has been conducted in Indonesian on the effect of the addition of iron to anti-TB drug therapy in patients. This study aimed to explore the effect of iron supplementation in antiTB drug therapy on the IFN- $\gamma$ level in spondylitis tuberculosis patients.

\section{Methods}

A single-blind randomized control trial study was conducted in Dr. Hasan Sadikin General Hospital, Bandung, Indonesia from December 2018 to March 2019. Respondents were randomly recruited using a consecutive approach based on the inclusion criteria, resulting in 34 respondents being recruited. This study was approved by Dr. Hasan Sadikin General Hospital ethics committee in August 2018 (LB.04.01/ A05/EC/257/VIII/2018).

The population of this study was outpatient spondylitis TB patients aged 19-15 years old with an sTfR level of $>21.7 \mathrm{mg} / \mathrm{L}$ treated at the Spine outpatient clinic of the Orthopaedics and Traumatology Department, Dr. Hasan Sadikin Bandung General Hospital (RSHS) and had never received anti-tuberculosis drug therapy.

Patients were divided into two groups of 17 people each. The first group was the control group. In this group, patients were treated with anti-tuberculosis drugs (2RHZE) without iron supplementation. The second group was the experimental group in which patients were treated with anti-tuberculosis drugs (2RHZE) supplemented with iron (357mg iron polymaltose (III))

All patients went through anamnesis, and clinical examinations were carried out by checking the vital signs and performing physical examination to obtain the history of the disease and clinical diagnosis. Furthermore, venous blood were drawn for examination of Hemoglobin level, LED, sTfR level, and Interferon- $\gamma$ level. These examinations were performed before therapy and after the intensive phase of therapy, which was two months after the therapy was started.

Data were then analyzed statistically after the research objectives and hypothesis. Significance tests used to compare the characteristics of the two study groups were the independent t-test for data with normal distribution and the MannWhitney test for data that were not normally distributed. Data obtained were recorded in a specific form and then processed using the SPSS version 25.0 for Windows.

\section{Results}

Table 1 explains the significance of pre-therapy between the control group and the experiment group. In age, sTfR, LED, and $\mathrm{Hb}$ variables, the significance level $(\alpha)$ of 0.05 was used. Results of the analysis on age, sTfR, LED, and Hb variables presented a $p$ value of $>0.05$, meaning that all pre-therapy variables the control group were equivalent (i.e. different but not significant) with the experimental group. In the sex variable, the significance level of $(\alpha)=0.05$ was used, resulting in a value of $p>0.05$, meaning that the pre-therapy variable for sex was equivalent (different but not significant) between the control group and experimental group. In the IFN- $\gamma$ variable, the significance level of $(\alpha)=0.05$ was used. The IFN- $\gamma$ variable presented a value of $p>0.05$, meaning the variable before therapy in the control group was equivalent (different but not significant) with the experimental group.

Table 2 explains the significance of posttherapy between the control group and the experiment group. In the sTfR, IFN- $\gamma$, LED, and $\mathrm{Hb}$ variables, the significance level of $(\alpha)=0.05$ was used. The sTfR and IFN- $\gamma$ variables had $p$ values of $<0.05$, meaning that the variables of 
MFN Perdana et al.: Effect of Iron Supplementation in Anti-Tuberculosis Drug Treatment on Interferon- $\gamma$ Level in Tuberculosis Spondylitis Patients

Table 1 Pre-treatment Significance Test Results

\begin{tabular}{|c|c|c|c|}
\hline Variable & Control & Experiment & $\mathbf{p}$ \\
\hline \multicolumn{4}{|l|}{ Age (year) } \\
\hline Average & 40.29 & 31.88 & \multirow{3}{*}{$\begin{array}{c}0.054 \\
\quad \#\end{array}$} \\
\hline SD & 12.89 & 11.65 & \\
\hline Median & 43.0 & 30 & \\
\hline \multicolumn{4}{|l|}{ Sex } \\
\hline Male & 9 & 8 & \multirow{2}{*}{$\underset{\wedge}{0.732}$} \\
\hline Female & 8 & 9 & \\
\hline \multicolumn{4}{|l|}{ sTfr pre } \\
\hline Average & 57.92 & 56.12 & \multirow{3}{*}{$\begin{array}{c}0.982 \\
\quad \#\end{array}$} \\
\hline SD & 6.07 & 7.05 & \\
\hline Median & 57.09 & 55.59 & \\
\hline \multicolumn{4}{|l|}{ IFN- $\gamma$ pre } \\
\hline Average & 22.5 & 21.7 & \multirow{3}{*}{$\begin{array}{c}0.760 \\
\quad !\end{array}$} \\
\hline SD & 20.78 & 22.79 & \\
\hline Median & 8.21 & 6.53 & \\
\hline \multicolumn{4}{|l|}{ LED pre } \\
\hline Average & 52.76 & 57.12 & \multirow{3}{*}{$\begin{array}{c}0.519 \\
\#\end{array}$} \\
\hline SD & 16.39 & 22.54 & \\
\hline Median & 52.00 & 57.00 & \\
\hline \multicolumn{4}{|l|}{ Hb pre } \\
\hline Average & 10.55 & 10.09 & \multirow{3}{*}{$\begin{array}{c}0.544 \\
\#\end{array}$} \\
\hline SD & 1.68 & 2.59 & \\
\hline Median & 10.60 & 9.40 & \\
\hline
\end{tabular}

${ }^{\wedge}$ Chi Square test ; \# independent t test; ! Mann-Whitney test

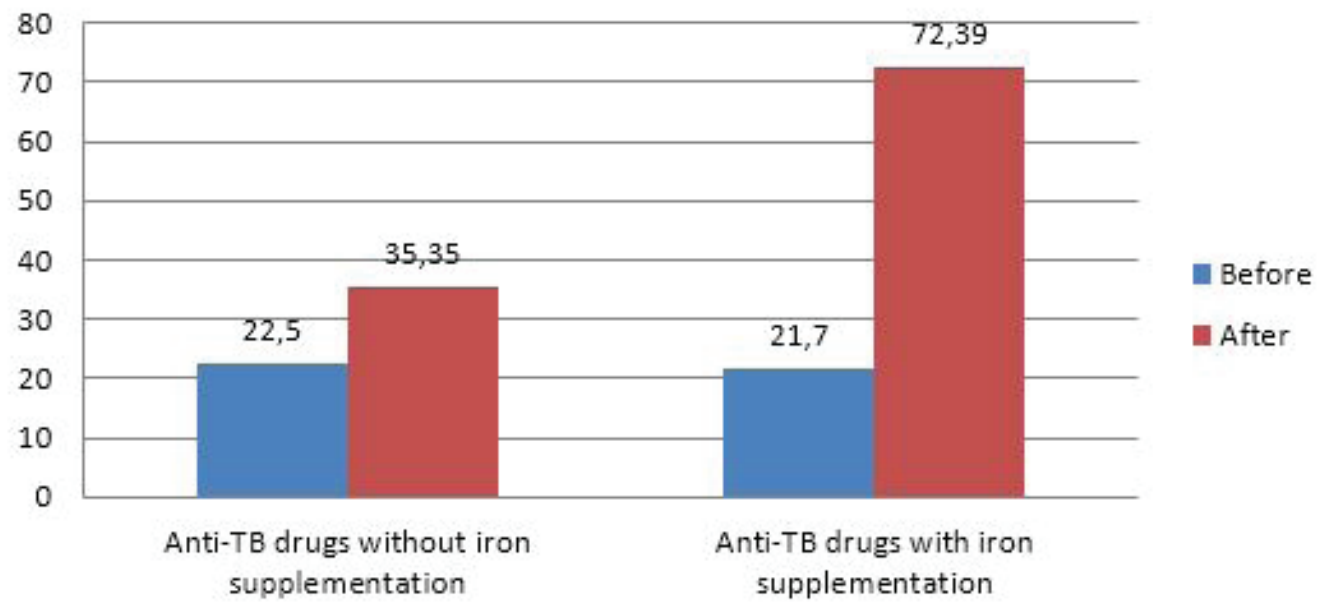

Figure 1 Comparison of IFN- $\gamma$ Levels in the Group Given Anti-TB Drugs without Iron Supplementation and the Group Given Anti-TB Drugs with Iron Supplementation 
MFN Perdana et al.: Effect of Iron Supplementation in Anti-Tuberculosis Drug Treatment on Interferon- $\gamma$ Level in Tuberculosis Spondylitis Patients

Table 2 Post-treatment Significance Test

\begin{tabular}{|c|c|c|c|}
\hline Variable & Control & Experiment & $\mathbf{p}$ \\
\hline \multicolumn{4}{|l|}{ sTfr post } \\
\hline Average & 36.26 & 20.51 & \multirow{3}{*}{$\begin{array}{c}0.000 \\
\#\end{array}$} \\
\hline SD & 3.77 & 3.48 & \\
\hline Median & 33.21 & 17.32 & \\
\hline \multicolumn{4}{|l|}{ IFN- $\gamma$ post } \\
\hline Average & 35.35 & 72.39 & \multirow{3}{*}{$\begin{array}{c}0.000 \\
\#\end{array}$} \\
\hline SD & 6.47 & 11.28 & \\
\hline Median & 33.7 & 71.3 & \\
\hline \multicolumn{4}{|l|}{ LED } \\
\hline Average & 31.59 & 30.41 & \multirow{3}{*}{$\begin{array}{c}0.802 \\
\#\end{array}$} \\
\hline SD & 14.50 & 12.63 & \\
\hline Median & 29.00 & 28.00 & \\
\hline \multicolumn{4}{|l|}{$\mathrm{Hb}$} \\
\hline Average & 11.14 & 11.84 & \multirow{3}{*}{$\begin{array}{c}0.262 \\
\#\end{array}$} \\
\hline SD & 1.66 & 1.88 & \\
\hline Median & 11.7 & 11.6 & \\
\hline
\end{tabular}

\#: independent t test

sTfR and IFN- $\gamma$ after therapy in the control group differed significantly from the experimental group. The LED and $\mathrm{Hb}$ variables presented a value of $p>0.05$, meaning that the variables LED and $\mathrm{Hb}$ after therapy in the control group were equivalent (different but not significant) to the experimental group.

\section{Discussion}

Iron is a micronutrient needed by the body. Iron is essential for the activity of enzymes involved in crucial cellular functions, starting from respiration to DNA replication. ${ }^{5,6}$ Iron deficiency decreases the ability of neutrophils to kill

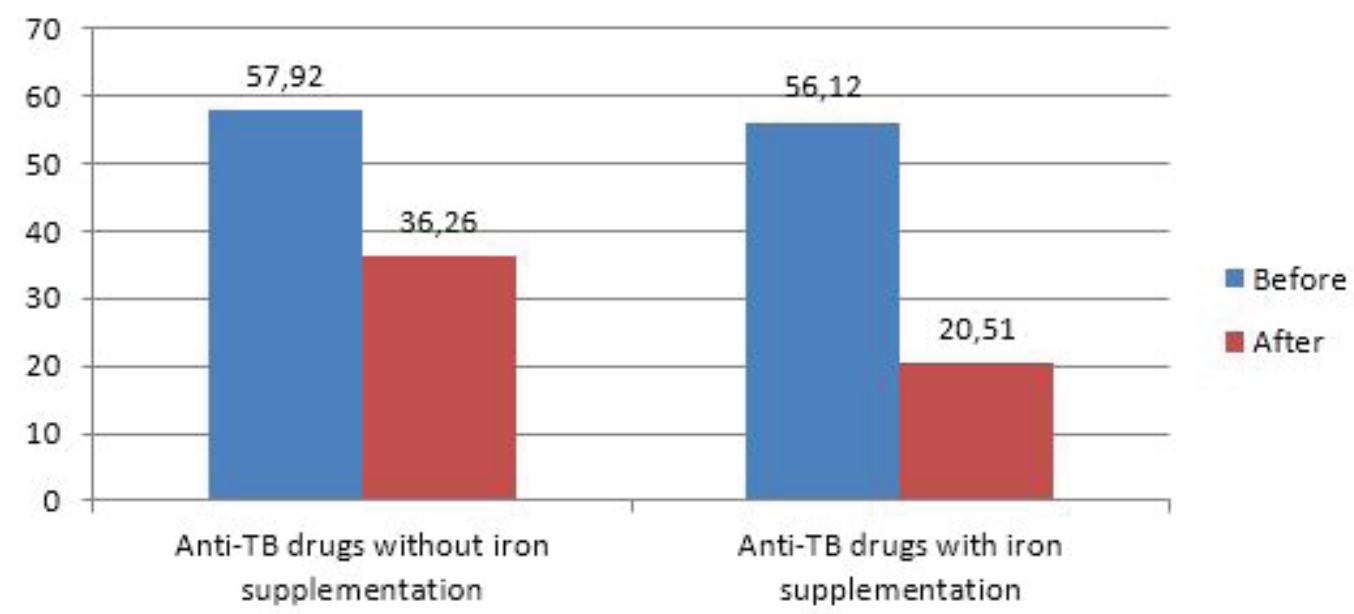

Figure 2 Comparison of sTfR Levels in the Group Given Anti-TB Drugs without Iron Supplementation and the Group Given Anti-TB Drugs with Iron Supplementation 
bacteria, decreases lymphocyte response, and interferes with Natural Killer (NK) cell activities. ${ }^{7}$ In this study, supplementation of iron in antiTB drugs therapy and its effects on treatment response was assessed through a decrease in sTfR level in tuberculosis spondylitis patients before and after therapy. There were differences in the results of the sTfR levels before and after the supplementation of iron in anti-TB drug therapy that is due to increased iron deposits of enterocytes from the iron supplementation and reduced receptors in plasma membranes.

Gamma interferon (IFN- $\gamma$ ) is the main activator of macrophages that can increase the ability of macrophages to kill microorganisms by cytolytic mechanisms. IFN- $\gamma$ is the cytokine that has the best potential for fighting against intracellular bacterial infections. Studies on the activation of antibacterial effector functions shows that IFN- $\gamma$ plays an important role. The loss of IFN- $\gamma$ can indicate an exacerbation of infectious diseases such as tuberculosis. ${ }^{8}$ IFN- $\gamma$ plays a crucial role in the protection of MTB but also influences the cellular iron status. Activation of IFN- $\gamma$ in monocytes regulates transferrin receptor (TfR) on the cell surface and the amount of iron macrophage gained from holo-transferrin are important in this mechanism. A decrease in IFN- $\gamma$ levels indicates a microbacterial infection. The monocyte-derived macrophages feed on intracellular bacteria, such as Mycobacterium, which results in the secretion of interleukin-12 (IL-12). IL-12 binds to its receptors on T-lymphocytes and NK cells, where it can trigger secretions from IFN- $\gamma$. IFN- $\gamma$ will then be bound to the heterodimeric receptors on the macrophages and activate the microbial destruction function through the transducer's signal mechanism. ${ }^{6,8}$ IFN $-\gamma$ is the main activator of macrophages to increase the ability of macrophages to kill microorganisms by cytolytic mechanisms. This effect of IFN- $\gamma$ is gained through increased the production of reactive oxygen intermediates, including hydrogen peroxide, nitric peroxide, and indoleamine dioxygenase. IFN- $\gamma$ strengthens the cytolytic activity of Natural Killer (NK) cells and also activates endothelial cells and neutrophil cells. ${ }^{8}$ Increased levels of IFN- $\gamma$ can be used as a healing marker in tuberculosis patients. ${ }^{9}$ In this study, an increase in IFN- $\gamma$ levels was seen from an average of $21.7 \mathrm{pg} / \mathrm{mL}$ to an average of 72.39 $\mathrm{pg} / \mathrm{mL}$ after the therapy in the IFN- $\gamma$ treatment group receiving anti-tuberculosis drugs with iron supplement. This is in line with findings from various studies in pulmonary tuberculosis patients, showing an increase in the IFN- $\gamma$ level after iron supplementation.

This study also used ESR as a measuring tool to assess the inflammatory process in spinal tuberculosis infections. Although ESR is a nonspecific marker in the inflammatory process, this examination is a simple examination that can be performed by peripheral laboratories and is a parameter for assessing therapeutic response and prognosis. ${ }^{10}$ Changes in ESR were seen, albeit statistically insignificant.

Findings in this study correlate with those of previous studies on patients with pulmonary tuberculosis, in which the study suggested that administration of iron in pulmonary tuberculosis accelerates healing, which is characterized by increased IFN- $\gamma$. In a study conducted by Djoko Trihadi in 2009 that involved 252 respondents with pulmonary tuberculosis with irondeficiency anemia without chronic disease and good nutritional status, it was demonstrated that iron supplementation increases the conversion of sputum smear in the experimental group by + $100 \%$, increasing the IFN- $\gamma$ in the experimental group by $+324.84 \% .{ }^{11}$ It this study, it was also evident that the addition of iron into the antituberculosis drug therapy in tuberculosis spondylitis patients increased the IFN- $\gamma$ level in the experiment group by $+333,59 \%{ }^{11}$

It is concluded that the administration of anti-tuberculosis drugs with the addition of iron can increase the body's immune response as indicated by increasing levels of IFN- $\gamma$. The limitation of this study is the difficulties in achieving uniformity in regulating activity and food consumption to increase iron, and patient compliance to take iron every day. These limitations can be overcome in subsequent studies by involving patients with tuberculous spondylitis admitted to hospitals so patients' activity pattern, dietary pattern, and regularity in iron consumption can be controlled.

\section{References}

1. Tuli S. Tuberculosis of the Skeletal System: Bones, Joints, Spine and Bursal Sheaths: Jaypee Brothers,Medical Publishers Pvt. Limited; 2008; p. 3-8.

2. Schirmer P, Renault CA, Holodniy M. Is spinal tuberculosis contagious?. Int J Infectious Dis. 2010;14(8):e659-66.

3. Sakamoto K. The pathology of Mycobacterium tuberculosis infection. Vet Pathol. 2012;49(3):423-39.

4. Soppi ET. Iron deficiency without 
MFN Perdana et al.: Effect of Iron Supplementation in Anti-Tuberculosis Drug Treatment on Interferon- $\gamma$ Level in Tuberculosis Spondylitis Patients

anemia-a clinical challenge. Clin Case Rep. 2018;6(6):1082-6.

5. Anderson GJ, Frazer DM. Current understanding of iron homeostasis. Am J Clin Nutr. 2017;106(Suppl 6):1559S-66.

6. Waldvogel-Abramowski S, Waeber G, Gassner C, Buser A, Frey BM, Favrat B, Tissot JD. Physiology of iron metabolism. Transfus Med Hemother. 2014;41(3):213-21.

7. Kumar V, Choudhry VP. Iron deficiency and infection. Indian J Pediatr. 2010;77(7):78993.

8. O'Shea JJ, Gadina M, Siegel RM. Cytokines and cytokine receptors. Clinical Immunology: Elsevier; 2019. p. 127-55.
9. Sun $\mathrm{Q}$, Wei $\mathrm{W}$, Sha W. Potential role for mycobacterium tuberculosis specific il-2 and IFN- $\gamma$ responses in discriminating between latent infection and active disease after long-term stimulation. PloS one. 2016;11(12):e0166501.

10. Herring JA. Tachdjian's pediatric orthopaedics $5^{\text {th }}$ ed. US: Elsevier Health Sciences; 2013. p. 1024-76.

11. Subagyo DTL. Pengaruh suplementasi besi pada tuberkulosis paru dengan anemia defisiensi besi (kajian respon kesembuhan, respon imun, dan resistensi) [dissertation]. Semarang: Universitas Diponegoro; 2009. 